\title{
Ethics of Potential New Retail Employees: Relationships Between Ethical Perceptions and Grades of Future Retail Personnel
}

\author{
David J. Burns \\ Xavier University
}

\begin{abstract}
Retailers use a number of screening mechanisms to determine the suitability of potential new employees. Rarely, however, does the selection process address the ethics of potential employees. This study explores this issue by determining whether retailers can obtain an assessment of potential employees' ethical perceptions by using information that they are already gathering, namely students' grades. Although the findings do not suggest that grades can be used to differentiate students in all areas of ethical activity, they do suggest that grades may be used to differentiate between ethical evaluations in some areas, particularly situations that are particularly disturbing to practitioners.
\end{abstract}

\section{Introduction}

In part due to a number of recent well-publicized ethical/legal problems, the issue of ethics in business is receiving growing attention (Desplaces, Melcher, Beauvais \& Bosco, 2007; Lopez, Rechner, \& Olson-Buchanan, 2005; Pettijohn, Pettijohn, \& Taylor, 2008). Although this attention has focused on businesses and institutions of all types, the retailing industry has received an inordinate amount of this concern (Burns \& Brady, 1996). This increased concern is not without reason and warrants discussion.

First, of all business entities, retailers play a unique role in the marketing channel. They are the only type of business firm that must continually interact with consumers in order to succeed. The situations and practices that present themselves in the retailerconsumer relationship, especially those situations and practices that may be regarded as potentially ethically troubling, are particularly visible to consumers and to society as a whole (Hisey, 2002). Furthermore, consumers comprise the group in the marketing channel most vulnerable to the effects of potentially ethically troublesome situations and practices. As a result, ethics in selling relationships between retail salespeople and consumers has received a significant amount of research attention (Dubinsky, Nataraajan, \& Huang, 2004).

Retailers also fill a boundary-spanning role between consumers and vendors (Bettencourt, Brown, \& Mackenzie, 2005; Greyser, 1981). Retailers generally must attempt to satisfy the needs of their customers through interactions with vendors. As such, retailers must operate within the constraints imposed by their vendors (the vendors' continued operation and continued interest to supply the retailer in question is required) and the needs of their customers (if they do not satisfy their customers better than competing retailers, the retailer will be in business no longer). Ethics in purchasing relationships between retailers and vendors, however, has not received the same degree of research attention as has ethics in selling relationships between retailers and 
consumers. This is true even given the recent, well-publicized ethical problems uncovered in the buying departments of Kmart (Berner, 1996a, 1996b), JCPenney (Gerlin, 1995a, 1995b), and Home Depot (Zimmerman, 2007).

Unlike other industries, it is not uncommon for employees in retailing to engage in both buying (purchasing) and selling activities during their careers. When hiring prospective management employees, then, many retailers must do so with the likely prospect that the new hires will engage in both buying and selling activities sometime during their careers. Given the importance of the encounters between retailers and each of these external constituents (consumers and vendors), and given the magnitude of the effect that engaging in potentially ethically troublesome situations and practices may have on a retailer's long-term success (Hisey, 2002), it would appear that the ethical perceptions of potential new hires would be a major hiring concern.

The objective of this study is to provide a basis for understanding ethics in the relationship between retailers and consumers, and between retailers and vendors, among future retail personnel. Particularly, this study will examine whether the grades students receive in a retail buying course are related to their perceptions of potentially ethically troublesome situations in retail selling and in retail buying. In other words, can grades be used as a proxy for ethical perceptions when making hiring decisions in retailing? First, past research examining ethical perceptions in the retailer-consumer relationship from the point of view of the salesperson will be summarized. Second, past research examining ethics in the retail-vendor relationship from a buying point of view will be explored. Third, ethics assessment in the hiring process will be examined. Fourth, ethical perceptions of future retail personnel based on a number of potentially ethically troublesome situations and practices involving retail sales and retail buying will be related to the grades they received in a course in retail buying. Finally, conclusions relating to the selection of employees will be presented.

\section{Ethics}

Although the study of ethics has a long history (stretching over several millennia), the issue of "what are ethics?" has remained a point of disagreement. Most agree that ethics depend upon beliefs (cultural, philosophical, or religious) of what is right or wrong, but there is not agreement on what beliefs should form the basis for ethics (Lewis, 1985).

A similar situation exists with business ethics. Indeed, Lewis equates defining business ethics with "nailing Jell-o to a wall" (1985, p. 381). Nevertheless, Lewis (1985) suggests that business ethics consists of rules etc. used to assess what is right or truthful behavior in business situations (1985). More recent definitions proposed for business ethics are similar. Velasquez, for instance, defines business ethics as "a specialized study of right and wrong. It concentrates on how moral standards apply particularly to business policies, institutions, and behavior" (2006, p. 16) and Schwartz and Weber define business ethics as involving "any formal (i.e., identifiable) activity taking place among individuals, organizations, or other entities operating within or related to a business context that involves the explicit interaction and/or application of ethical (i.e., 
moral) standards" (2006, p. 386). Each of these definitions of business ethics relies on a designation of standards for determining right and wrong, but agreement on the theoretical basis for the standards for determining what is right or wrong is lacking. Indeed, Ferrell and Gresham (1985) suggest that there are five different dominant different philosophies which can form the basis for ethics.

Given the lack of agreement on the appropriate basis to determine right or wrong, business ethics in marketing-related settings have customarily been measured in two different fashions. The first is based on the degree to which respondents are troubled by a list of potentially ethically troublesome situations and practices (e.g., Vitell, Singh, \& Paolillo, 2007). The larger the number of situations and practices for which respondents are troubled and the greater the degree they are troubled are equated with higher ethical standards. The second way that business ethics is customarily measured involves the use of a relatively small number of potentially ethically troublesome scenarios where respondents are to assess the ethicality of the choices depicted in the scenarios based on the primary ethical philosophies (e.g., Marta, Singhapakdi, \& Kraft, 2008). This study will utilize both means of measuring business ethics.

\section{Ethics in the Retail Sales Environment}

The sales environment has received the majority of ethics attention in the area of retailing (Stevenson \& Bodkin, 1998). This attention appears to be warranted since the sales environment appears to be particularly prone to the development of ethically troublesome situations (Donoho, Herche, \& Swenson, 2003). Indeed, the retail sales position appears to possess several qualities increasing the likelihood that individuals in these positions will encounter potentially ethically troublesome situations and practices. Furthermore, the ethical behavior of retail salespeople appears to be particularly important to the success of retail organizations. Román and Ruiz (2005), for instance, observed that the ethical behavior of retail salespersons affects the quality of relationships with consumers and the degree of satisfaction consumers experienced.

Similar to the boundary-spanning role played by retailers, retail salespeople also are forced to play a boundary-spanning role. The duties of retail salespeople are not limited to satisfying the desires of their managers - they must also satisfy the desires of consumers. In practice, however, frequently the desires of managers and consumers conflict with one another, giving rise to an atmosphere where salespeople may be tempted to resort to ethically questionable practices. As a result of this "dual role," retail salespeople are responsible for a seemingly infinite variety of tasks (Hart, Stachow, Farrell \& Reed, 2007). Besides a quick overview of company policies and brief instruction in the retailer's POS systems (if applicable), retail salespeople are likely to receive little formalized training or socialization (Hart, Stachow, Farrell, \& Reed, 2007). Furthermore, a lack of direct supervision and unusual amounts of independence provide salespersons with the means to pursue ethically questionable activities (Inks, Avila, \& Chapman, 2004). Finally, Kopp (1993) suggests that all personal selling may be inherently unethical since salespeople are paid to promote their employer's merchandise, rather than what they actually believe to be best for the customer. Indeed, Howe, Hoffman, and Hardigree (1994) observed a positive relationship between 
unethical behavior and successful salesperson performance.

A number of studies have examined individuals' perceptions of potentially ethically troublesome situations in retail sales. In one of the first studies to gain broad recognition, Dornoff and Tankersley (1975-76) examined the ethical perceptions of retail managers using a number of vignettes of situations encountered in retailing. A replication of those studies by Gifford and Norris (1987) suggest that retail managers are increasingly "ethically-minded." Interestingly, Hawthorne, Robin and Reidenbach (1992) observed that retail managers are more ethical than retail salespeople based on the same instrument. Several of the vignettes used in these studies, however, likely more closely represent customer-orientation issues than pure ethics issues, possibly limiting the value of the research based on the Dornoff and Tankersley (1975-76) instrument.

A subsequent study by Dubinsky and Levy (1985) examined perceptions of retail salespeople on 38 potentially ethically troublesome retail sales situations and practices. They observed that retail salespeople did not consider a large portion of the situations to reflect problems of ethical concern. The retail salespeople did, however, believe that most of the ethical issues raised by the situations should be addressed by company policies. Sarma (2007) observed similar findings using a sample of retail sales personnel in India, except that he observed a lesser desire for policies. While examining perceptions of retail salespersons on 29 potentially ethically troublesome retail situations and practices, Dubinsky, Nataraajan, and Huang (2004) noted that perceptions may be affected by the moral philosophy employed by retail salespersons.

A number of studies have examined the ethical perceptions of students (or future business personnel) (e.g., Brinkman, 2002; Donoho, Herche, \& Swenson, 2003; Hudson \& Miller, 2005). Examining the ethical perceptions of students allows practitioners to better understand and/or anticipate the level of ethical awareness recent and prospective new hires may possess. In a longitudinal study of senior-level business students, Norris and Gifford (1988) examined perceptions of a number of questionable retail practices using the vignettes of Dornoff and Tankersley (1975-76). Their results suggest that, unlike those of managers, students' perceptions of ethical issues changed during that time. Furthermore, the students appeared to hold significantly "less ethical" perceptions than did retail managers. Burns, Lanasa and Fawcett (1990) and DuPont and Craig (1996) observed similar results. Based on the magnitude of the differences in ethical perceptions between students and practicing retail professionals, DuPont and Craig observed "these ethical perceptions apparently represent a decline from the current ethical standards of the contemporary retail industry. The emerging "new ethics" of the younger professionals will influence the industry long-range since the business ethics of the new generation appears to evidence a marked decline from current business practice" (1996, p. 825). DuPont and Craig (1996) also observed that entrylevel work experience and retail sales experience appear to further lower students' ethical perceptions, providing evidence that it is unlikely that the ethical perceptions of students will rise significantly during their career.

Given the aforementioned shortcomings of the Dornoff-Tankersley instrument, Burns 
and Smith (1990) examined students' perceptions based on the Dubinsky and Levy (1985) instrument. They observed similar results, in that they also observed the ethical perceptions of students to be lower than those of retail practitioners. Furthermore, Burns and Brady (1996) compared the ethical perceptions of U.S. students with those of Malaysian students. Given the importance of the ethical perceptions of business students, surprisingly, little recent research has examined this area.

\section{Ethics in the Retail Buying Environment}

Buying has gained renewed attention in retailing over the past couple of decades for a couple of reasons (Razzaque \& Hwee, 2002). First, as an industry characterized by low gross margins, retailing is extraordinarily susceptible to the adverse effects of ethically questionable buying practices. Concerning the issue of kickbacks, Gillman states, "while the vendors and buyers profit from kickback arrangements, retailers and consumers pay for it" $(1985$, p. 6). Second, retail customers have become increasingly demanding for specific products - when encountering stockouts retail customers often choose to shop elsewhere. Ethically questionable practices in retail buying have the potential of negatively affecting both a retailer=s product assortment and their in-stock position.

In the midst of this increased importance, evidence seems to indicate that the incidence of ethically questionable practices in the retail buying environment may be increasing (Park \& Stoel, 2005). Indeed, with the increasing attention being placed on supplier partnering, the situation may have worsened further (Atkinson, 2003; Pregman, 1997). Giese, for instance, states "there is arguably no area more susceptible to fraud than procurement" (2004, p. 43). Flanagan reports "a growing level of contention between buyer and seller. ... This is particularly seen in retailing" (1994, p. 29).

Although the issue of ethics in the vendor-retail salesperson relationship appears to be of significant importance, surprisingly little research has examined this area (Pretious \& Love, 2006). Robicheaux and Robin (1996) addressed the issue of the relative lack of research in this area by suggesting several reasons for it. First, ethical problems in the retail buyer-vendor relationship are relatively obscure. In fact, unless problems in this relationship are communicated via the news media, few parties outside those directly involved are aware of the happenings. Even when problems are communicated by the news media, often they are communicated only in the business press with the general public hearing little.

Robicheaux and Robin (1996) suggest that a second reason for the relative lack of research into ethical problems in the retail buying environment is the identity of the "victims" of such problems. In the retail buyer-vendor relationship, the direct victims of ethical problems are businesses and/or business people - people and parties that are generally regarded as being discerning and financially secure. These victims are viewed as being responsible for their own victimization and being able to easily handle any resulting loss. (It should be noted that ethical problems in the retail buying environment do affect consumers, but in an indirect fashion).

In her research of ethical problems in the retail buying environment in small apparel 
retailers, Arbuthnot (1997) identified an inventory of issues viewed to be ethically troubling to retail owners and buyers. She observed that many of the situations are frequently encountered, suggesting that ethical problems may be pervasive in the retail buying environment, at least where small apparel retailers are concerned. Burns and Arbuthnot (1998) observed that future retail personnel perceived most of the issues to be ethically troublesome.

Robicheaux and Robin (1996) examined possible ethical problems in the retail food industry. They compared the ethical evaluations of food industry executives (grocers and brokers) and students (MBA, EMBA, and senior-level undergraduate) on four practices that likely pose ethical dilemmas for industry personnel. The practices included slotting allowances, volume discounts, diversion, and an attempt to interfere with a competitor's relationship with a desired customer. They observed that business students tended to view the practices as occurring less frequently than did practitioners, but they tended to believe that they would be more likely to engage in the practices. Furthermore, each of the groups of respondents viewed each practice to be similar in ethical severity with the exception of the final practice - interfering with a competitor=s relationship with a desired customer. Each group of respondents viewed the final practice to be significantly more unethical than each of the other three practices. Burns (2004) observed ethical perceptions of these practices by students to be related to their intentions to engage in the activities.

\section{Ethics, Personnel and the Hiring Process}

Organizations (including business organizations) can be expected to affect the ethical perceptions and behavior of their members (Hatch \& Cunliffe, 2006; Pettijohn, Pettijohn, \& Taylor, 2008). Through socialization, for instance, a business' culture, or the shared principles and values of a business, can be passed to its members (Daft \& Noe, 2001). A business' culture, in turn, enforces behavior and imposes attitudes upon its members by establishing standards and expectations.

A business' culture can be reinforced and maintained through the selection process (Daft \& Noe, 2001). In part, a business exhibits the qualities of its individual members, including the ethical perceptions of its members (Stoner \& Freeman, 1989). By hiring individuals exhibiting a "good match" with the culture, the socialization process will be easier since less change or modification will be expected of new employees (Mujtaba \& Sims, 2006; Pettijohn, Pettijohn, \& Taylor, 2008; Schwepker \& Good, 2007; Telford \& Gostick, 2005). This suggests that an organization, such as a retailer, which wishes to maintain a certain ethical stance may desire to pay attention to the ethical standards and orientations of individuals entering the organization. The ethical standards of individuals entering business, however, may pose a problem. Although Spake, Megehee, and Franke (2007) suggest that the ethical standards of students may have stabilized, they have done so after a long and steady decline (DuPont \& Craig, 1996; Loo, Kennedy, \& Sauers, 1999). It appears, therefore, that the ethical perceptions of potential new hires may be a major hiring concern.

Hiring, or the employee selection process, is a very important activity in retailing. The 
success of an organization, including retail organizations, is dependent on the qualities of the individuals who comprise that organization (Robbins, 2003). Indeed, "people are the most important asset of any organization" (Mondy, Holmes, \& Flippo, 1983, p. 293). In fact, organizations are simply "social inventions formed for the purpose of accomplishing tasks or goals" (Roberts \& Hunt, 1991, p. 3). Retailers use a number of screening mechanisms to determine whether a potential new hire has the background and capabilities needed to adequately perform the duties that would be required of them. Rarely, however, does the selection process specifically address the ethics of the potential new hire (with the exception of obvious issues, such as the existence of a police record). This is not surprising given the sensitivity associated with the issue and the difficulty in obtaining an accurate appraisal of an individual's ethical perceptions using customary screening procedures. Is there a way for retailers to obtain an assessment of potential new hires ethical perceptions using information that they are likely already gathering? Specifically, is there a relationship between ethical perceptions and academic performance?

\section{Ethics and Academic Performance}

Very little research has examined the relationship between ethics and academic performance. Glover, Bumpus, Logan, and Ciesla (1997) observed a positive relationship between ethics and need for achievement among college students, but did not explore the relationship with actual academic performance. The academic performance of students is typically measured by the grades they receive - the higher the grades received by the student, the better their academic performance is deemed to be (Reardon, Payan, Miller \& Alexander, 2008). Using grades as a proxy for academic performance seems appropriate since grades represent instructors' assessments of the extent that students have met course objectives. Indeed, grades and academic performance are generally used interchangeably (Chen \& Peng, 2008).

Terpstra, Rozell and Robinson (1993) examined the relationship between ethics and academic performance based on the students' overall GPA as it relates to insider trading and observed no relationship. Lane, Schaupp, and Parsons (1988), however, believe that a relationship may exist between students' ethics and their academic performance by virtue of the academic experience and the grading process. In fact, Lane, Schaupp, and Parsons (1988) suggest that a negative relationship may exist between students' grades and their ethical perceptions (students receiving higher grades possess lower ethical perceptions). They observed that students often subordinated ethics to the demands of academic achievement. Furthermore, they observed that the philosophy expressed by a majority of the students was "winning is everything." Moreover, grades were viewed as the primary outcome of their education (as opposed to knowledge or skill). In their quest to achieve high grades, students reported numerous questionable activities.

Unfortunately, little research has directly examined the contentions of Lane, Schaupp, and Parsons (1988). There has been some research that has addressed similar issues, however. Klein, Levenburg, McKendell, and Mothersell (2007), for instance, observed that students who cheat in class tend to possess lower GPAs than those who do not. 
This study, however, only examined the activity of cheating, with no attempt to explore ethical attitudes toward other academic practices or toward practices in the business environment.

A couple of studies have examined the related issue of students' self-perceived academic performance. Smith, Davy, and Easterling (2004), for instance, observed a weak relationship between self-perceived academic performance and likelihood to cheat among students majoring in management and marketing, whereas Smith, Davy, Rosenberg, and Haight (2002) did not observe such a relationship with students majoring in accounting. The weak and contradictory results likely result from the selfreport nature of academic performance (measured on a five-point scale) and the examination of a single intention (likelihood to cheat). The relationship between ethical perceptions and grades received has not yet been examined.

\section{Research Method and Operationalization of Variables}

The objective of this study is to empirically examine the relationship between ethical perceptions and the grades received by collegiate business students in a course in retail buying. A questionnaire is utilized to assess ethical perceptions and grades are the actual grades received by students. Each will be discussed.

Ethics in a retail context is generally measured based on lists of ethical scenarios or questionable situations and practices, where individuals are asked to determine the relative ethicality of each item (Fraedrich \& lyer, 2008). This approach permits a measurement of individuals' ethicality relative to a group perspective. The questionnaire used in the study consisted of instruments to determine perceptions of potentially ethically troublesome situations and practices in retailing. The first instrument examined perceptions of potentially ethically troublesome situations and practices in retail selling. The second and third instruments examined perceptions of potentially ethically troublesome situations and practices in retail buying.

The first instrument was developed by Dubinsky and Levy (1985; Levy \& Dubinsky, 1983) and is displayed in Table 1. The authors used the Nominal Group Technique (NGT) (Delbecq, Van De Ven, \& Gustafson, 1975) to generate the scale items. The resulting scale consists of 38 items. For each item, subjects are asked to "Assume you are presently employed in a retail establishment as a salesperson. Please answer the following question for each of the situations presented: Does the situation present an ethical question for you? (Do you feel that the situation pressures you into taking actions that are inconsistent with what you feel is right?)" Subjects were asked to respond to each question using a seven-point scale where "1" represented "definitely no" and "7" represented "definitely yes," which is identical to that used in the instrument development studies.

Table 1

Dubinsky and Levy Instrument

1. Don't offer information about an upcoming sale that will include merchandise the 
customer is planning to buy

2. Have to sell nonsale items at full price when the items were accidentally placed with the sale merchandise.

3. Don=t assist customers you believe are less likely to buy.

4. Make excuses to customers about unavailable merchandise that is not yet in stock or is sold out.

5. Sell a more expensive product when a less expensive one would be better for the customer.

6. Ignore a prospective customer for one you believe will be a better one.

7. Use of a sales contest for sales associates in order to generate sales to customers.

8. Hide merchandise that you want and are waiting for the store to mark down.

9. Charge markdown price to customers for similar full-price merchandise.

10. Make a promise you cannot keep regarding the time when something will be ready.

11. Give preferential treatment to certain customers.

12. Sign time sheet incorrectly for time worked.

13. Customer damages a product in the store and wants a markdown.

14. Make excuses when merchandise is not ready for customer pickup.

15. Buy merchandise before it is available to the customer.

16. Perform your job with inadequate job information or training.

17. Sell the product as an exclusive, when it is in fact available in other stores.

18. Pressure from fellow sales associates not to report theft.

19. Hoard free samples that are meant for customers.

20. Give incorrect change to customers on purchase.

21. Peer pressure not to say anything to management about other sales associates' personal problems.

22. Don't sell the last unit because you want to purchase it yourself.

23. Refuse return by customer when you think the item should be accepted.

24. Take return from customer when you think the item should not be accepted.

25. Pressure from a friend or family member not entitled to a discount to give him or her your employee discount.

26. Don't tell the complete truth to a customer about the characteristics of a product.

27. Charge full price for a sale item without the customer's knowledge.

28. Offer to give a friend (or family member) not entitled to a discount your employee discount.

29. Take away sales from a fellow sales associate.

30. Pressure customers into making a sale.

31. Don't get a check authorization when required.

32. Telephone customer wants help, but you decide not to assist him/her.

33. Try to get an employee to quit.

34. Salesperson not working or selling up to his/her potential so as not to offend another employee.

35. Date or socialize with the management.

36. Date or socialize with fellow employees who are not in management.

37. Inexperienced salesperson receives an unfair workload.

38. Sell merchandise that is not of good quality. 
(Dubinsky \& Levy, 1985, pp. 6-8)

The second instrument was developed by Arbuthnot (1997) (displayed in Table 2). The initial twenty-two scale items were identified through personal interviews with eighteen owners/buyers of small retail apparel stores and were subsequently refined through follow-up personal interviews in a method similar to a Delphi technique. Additional items were developed based on the responses from a sample of 106 independently owned specialty store owner/buyers who responded to an open-ended question asking them to list the vendor-related experiences they had encountered that they considered as unethical. (Items were included only if they were not included in the initial list of twentytwo). The final scale consists of 37 items. For each situation or practice, subjects were asked to answer the following question: "Do you perceive the situation as unethical?" Subjects were asked to respond to each situation using a seven-point scale where "1" represented "definitely no" and "7" represented "definitely yes."

\section{Table 2}

\section{Arbuthnot Instrument}

1. Vendor has large minimum order requirements.

2. Must purchase products from the vendors 6 months in advance of delivery.

3. Vendor ships incomplete orders.

4. Vendor provides no notification of late shipments

5. The vendor overcharges for shipping.

6. The vendor ships orders late.

7. The vendor provides no notification when products are not in stock.

8. The vendor provides no notification of canceled orders.

9. The vendor has a very limited return policy.

10. The vendor ships defective merchandise.

11. The vendor provides substitutions for ordered merchandise.

12. The vendor does not send sales representatives to their customers' stores.

13. The vendor provides products of poor quality.

14. The vendor provides products with poor fit.

15. The vendor does not accept responsibility for problems.

16. The vendor cancels back orders.

17. The vendor promises merchandise it cannot deliver.

18. The merchandise sent by the vendor does not match the sample.

19. The vendor ships merchandise that was not ordered.

20. The vendor changes the price after the order is placed.

21. The vendor ships products which are seconds.

22. The vendor adds to, or pads, the order.

23. The vendor sells the same merchandise to competitors.

24. The vendor refuses to authorize returns or does not credit for returned merchandise.

25. Vendor's accounts receivables do not agree with the prices of the products shipped.

26. The vendor switches style and size tags to agree with order. 
27. The vendor provides assistance to large retailers which they do not provide to small retailers.

28. A vendor goes out of business while owing retailers money.

29. The vendor double ships orders.

30. The vendor pre-dates invoices.

31. The vendor does not arrange for shipping for returns.

32. A vendor sells off-price merchandise as first quality at regional markets.

33. The vendor accepts orders with no intention of shipping.

34. Vendor uses retailer's customer list to directly contact them regarding outlet store sales and mail order service.

35. Sales representative does not show product lines unless the retailer commits to ordering.

36. Vendor employs insufficiently trained personnel.

37. The vendor bills before the merchandise is shipped.

(Arbuthnot, 1997, pp. 750, 753)

The third instrument included the scenarios utilized by Robicheaux and Robin (1996) and the Multidimensional Ethics Scale developed by Reidenbach and Robin (1988, 1990, 1991 with Dawson). The scenarios consisted of descriptions of four distributive practices (slotting allowances, volume discounts, diversion, and an attempt to interfere with a competitor's relationship with a desired customer) that likely pose ethical dilemmas in retail buying and are perceived by food industry executives as being fairly common. The scenarios are displayed in Table 3. Once reading each scenario, respondents were asked to respond to the Multidimensional Ethics Scale (MES) based on a seven-point bi-polar rating scale.

Table 3

Scenarios Based on Selected Distribution Practices

\section{Slotting Allowances}

Pillsbury plans to introduce a new line of frozen waffles with three SKUs. The marketing budget includes a national allocation of $\$ 6,000$ per percentage point of All Commodity Volume (ACV) to cover slotting costs.

In a market that represents $3 \%$ of national $\mathrm{ACV}$, the slotting allowance budget is $\$ 18,000$. Based on individuals retailer ACVs in the market, the funds should be allocated as follows: Retailer A - $\$ 9,900$, Retailer B - $\$ 3,600$, Retailer C - $\$ 2,340$, Retailer D - $\$ 1,800$ and all other Retailers - $\$ 360$.

During the initial meetings with the retailers, the manufacturer learns that the two largest grocers, $A$ and $B$, have fixed slotting fees of $\$ 4,000$ and $\$ 1,000$, respectively, for each SKU. Thus, they demand allowances of $\$ 12,000$ and $\$ 4,500$ to stock the three new SKUs. This nearly exhausts the area budget. Sales indicate that the other retailers in the market tend to follow Retailer A's decisions. 
ACTION: Pillsbury's marketing people redistribute the allocated funds to meet A's and B's demands. Allocations to $C$ and $D$ are reduced proportionately and the all other category is eliminated altogether.

\section{Diversion}

Lemming Foods is a national grocery retailer. Pillsbury's broker in Atlanta has offered an excellent merchandising program to Lemming=s southeastern buying office, encompassing Pillsbury waffles, Minute Maid Orange Juice and Polandar All Fruit. The program incorporates local merchandising funds from all three vendors to provide advertising monies, display incentives, and a Hawaiian Vacation consumer promotion.

A Lemming buyer on the west coast has advised the southeastern division buyers that they can buy Pillsbury waffles for $\$ 1.20$ per case less than the southeastern price. Transportation for the west coast is $\$ .20$ per case. The diversion profit to the southeastern division is $\$ 1.00$ per case.

The west coast division offer is a spot opportunity and requires an immediate decision. There is no time to contact the local broker to ask Pillsbury to meet the west coast offer.

ACTION: Lemming orders the merchandise even though they realize that the local broker will be denied a commission on the sale.

\section{$\underline{\text { Volume Discounts }}$}

A fruit juice vendor that markets the leading brand in the southeast wants to achieve a retail price of $\$ .99$ per $64 \mathrm{oz}$. unit in a very large and very competitive market. The vendor offers an ongoing performance allowance of $\$ 2.50$ per case off the $\$ 9.00$ per case ( 6 units per case) list price. In addition, it offers for 30 days a volume discount of $\$ .80$ per case for customers who ship 10,000 or more cases during the first month of the promotion.

This enables a single very large retailer in the market to enjoy a net cost per unit of $\$ .95$ and to retail that at $\$ .99$ - earning a $4 \%$ margin on retail. No other retailer in the market can meet the volume needed to qualify for the added incentive. However, they all feel compelled to meet the price point of $\$ .99$. Thus, they all pay $\$ 1.08$ per unit and lose $\$ .09$ on each sale at $\$ .99$.

ACTION: The vendor is pleased as the promotion achieved an across the board retail price of $\$ .99$ on their brand but limited their liability for the deep cut allowance package. A decision is made to continue the volume discount indefinitely. The smaller retailers are disadvantaged.

\section{Expanding Distribution}


Tom Simpson is the new National Sales Manager for Poncho's Frozen Foods - a firm which dominates its category with $75 \%$ brand share. Their principal competitor is Jaurez Specialties. Smith's, a small regional grocery chain, is the only account in the southeast which does not stock Poncho's and carries Jaurez products exclusively. Gaining this account has been a major goal of Poncho's for some time.

Henry Johnson owns Food Zebra, a retail competitor of Smith's. Henry has a firm policy against selling any product below cost. His position is well known throughout the area. Tom and Henry are old friends. Tom knows that Henry will maintain complete confidentiality on any deal they make.

ACTION: Tom persuades Henry to run a "buy one get one free" promotion on Juarez products at a $10 \%$ profit on retail. Tom offers to cover the cost of this promotion with free Poncho=s merchandise. All that Henry has to promise is complete confidentiality.

OUTCOME OF THE ACTION: When Smith sees the Food Zebra promotion and recalls Henry Johnson's attitude toward sales below cost, he complains to the Juarez broker and insists that he get whatever promotion was offered to Smith's. The Juarez broker insists that no promotion was offered; but, Smith doesn't believe him. He retaliates by dropping all Juarez merchandise and replaces it with Poncho's. Tom Simpson accomplished his goal.

(Robicheaux \& Robin, 1996, pp. 436-438)

The MES was developed with validity as an overriding concern. The scale, which consists of eight items (Table 4) and three factors, resulted from a multi-stage process and appears to be valid and reliable (Reidenbach \& Robin, 1990). The first factor was comprised of items addressing ethical philosophies. Reidenbach and Robin (1990) describe this factor as fairness, justice, goodness and rightness (moral equity). The second factor addresses a culturally relativistic perspective (relativism). The final dimension addresses a deontological perspective based on implied obligations, contracts, or duties (contractualism). For each scenario, the MES was followed by questions concerning the likelihood that the respondent would engage in the practice described (behavioral intentions) and their perceived commonality of the practice in the food industry. Subsequent research provides additional evidence of the reliability and validity of the measure (McMahon, 2003).

\section{Table 4}

\section{Multidimensional Ethics Scale}

Fair/Unfair

Just/Unjust

Morally Right/Not Morally Right

Acceptable/Unacceptable to my Family 
Traditionally Acceptable/Unacceptable

Culturally Acceptable/Unacceptable

Violates/Does not Violate an Unspoken Promise

Violates/Does not Violate an Unwritten Contract

(Reidenbach \& Robin, 1990, p. 643)

Finally, students' academic performance was assessed by the grade they received in the course in which they completed the questionnaire. This grade was used instead of overall grade point average (GPA) for several reasons. First, since GPA can often be significantly affected by adjustment difficulties encountered by students during their first year of college, GPA may not provide an accurate picture of academic achievement. This is especially true since a significant percentage of the students included in the sample were transfer students who completed the first year or two of college at another institution. Transfer students would not have their grades from their initial year or two of college included in their GPA. Second, GPA is affected by the nature of the courses a student takes as well as the instructors in those courses. Students' GPAs, therefore, are not necessarily a direct reflection of relative academic accomplishment. The grade received in a retail buying course (the course in which the questionnaire was administered) was chosen since its subject matter most closely matches that area under consideration. Furthermore, the uniformity of different sections can be guaranteed since they are all taught by a single instructor.

The perceptions of the sample on the potentially ethically troublesome situations and practices in retail selling instrument (Dubinsky \& Levy, 1985) and of the retail buying instrument (Arbuthnot, 1997) were related to the grade they received in a course in retail buying. Correlation analysis was used to determine the strength and the significance of the relationships. Furthermore, individual scores were also determined for each of the Robicheaux and Robin's (1996) scenarios for each individual based on the MES factors. Scores for each MES factor, behavioral intentions and perceived prevalence of the practice for each scenario were correlated with the grade received in the course on retail buying.

\section{Sample}

The sample was drawn from undergraduate students enrolled in sections of a course in retail buying offered within a college of business. These students were chosen for several reasons. First, these students are likely to be knowledgeable of the retail buying environment. Second, since the retail buying course is required only for students who are pursuing a degree in retailing, these students will also likely pursue a career in retailing upon graduation. Student participation was solicited during their retail buying class. Students were requested to anonymously complete a survey questionnaire during class time without discussion. No nonresponse was noted. The resulting sample consisted of 144 usable responses.

\section{Hypotheses}


The objective of this study is to identify whether a retailer can assess a potential new retail hire=s ethical positions via a proxy. Specifically, the focus of this study is on identifying whether students' ethical perceptions are related to the course grade that they received in a course on retail buying. Based on the observations of Lane, Schaupp and Parsons (1988), it is hypothesized that a negative relationship exists between students' grades and their ethical evaluations of selected ethically questionable situations and practices in retail selling and retail buying. In other words, students receiving higher grades are hypothesized to hold lower ethical perceptions of ethically questionable situations and practices in retail selling and retail buying than students receiving lower grades.

\section{Findings}

A summary of the strengths and significance of the relationships between students' grades and responses for each potentially ethically troublesome retail selling situation or practice is presented in Table 5. A summary of the strengths and significance of the relationships between students' grades and responses for each potentially ethically troublesome retail buying situation or practice is presented in Table 6. Finally, a summary of the strengths and significance of the relationships between students' grades and assessment of each of the buying scenarios in the retail food industry is presented in Table 7.

\section{Table 5}

\section{Correlations Between Students= Perceptions of Potentially Ethically Troublesome Situations in Retail Sales and Grade Received in a Retail Buying Course}

$\begin{array}{ccc}\text { Situation Number } & \text { Correlation } & \text { Significance } \\ 1 & -.018 & .827 \\ 2 & .041 & .628 \\ 3 & .007 & .936 \\ 4 & -.123 & .142 \\ 5 & -.041 & .625 \\ 6 & -.046 & .588 \\ 7 & .127 & .131 \\ 8 & .048 & .570 \\ 9 & -.067 & .429 \\ 10 & .015 & .856 \\ 11 & .087 & .301 \\ 12 & .073 & .389 \\ 13 & -.019 & .822 \\ 14 & -.082 & .331 \\ 15 & .018 & .833 \\ 16 & -.180 & .032^{*} \\ 17 & .122 & .148 \\ 18 & .011 & .900 \\ 19 & .036 & .668\end{array}$




\begin{tabular}{|c|c|c|}
\hline 20 & -.047 & .578 \\
\hline 21 & -.080 & .345 \\
\hline 22 & .017 & .837 \\
\hline 23 & .042 & .622 \\
\hline 24 & -.137 & .104 \\
\hline 25 & .037 & .665 \\
\hline 26 & .019 & .826 \\
\hline 27 & -.018 & .829 \\
\hline 28 & .099 & .243 \\
\hline 29 & -.056 & .510 \\
\hline 30 & -.092 & .274 \\
\hline 31 & -.031 & .718 \\
\hline 32 & -.031 & .710 \\
\hline 33 & -.034 & .684 \\
\hline 34 & .051 & .543 \\
\hline 35 & -.032 & .703 \\
\hline 36 & -.042 & .617 \\
\hline 37 & -.028 & .743 \\
\hline 38 & -.009 & .916 \\
\hline
\end{tabular}

\section{Table 6}

Correlations Between Students' Perceptions of Potentially Ethically Troublesome Situations in Retail Buying and Grade Received in a Retail Buying Course

$\begin{array}{crc}\text { Situation Number } & \text { Correlation } & \text { Significance } \\ 1 & -.010 & .909 \\ 2 & -.082 & .330 \\ 3 & .095 & .260 \\ 4 & .110 & .192 \\ 5 & .064 & .446 \\ 6 & -.044 & .604 \\ 7 & .052 & .540 \\ 8 & .111 & .188 \\ 9 & -.015 & .859 \\ 10 & .006 & .942 \\ 11 & .047 & .575 \\ 12 & -.146 & .082 \\ 13 & -.024 & .777 \\ 14 & -.008 & .924 \\ 15 & .008 & .924 \\ 16 & -.106 & .207 \\ 17 & .115 & .170 \\ 18 & .012 & .886 \\ 19 & .073 & .383 \\ 20 & .018 & .830 \\ 21 & -.083 & .323\end{array}$




$\begin{array}{cccc} & 22 & .004 & .963 \\ & 23 & .027 & .750 \\ & 24 & .060 & .480 \\ & 25 & -.041 & .625 \\ & 26 & .103 & .225 \\ & 27 & .112 & .183 \\ & 28 & -.093 & .272 \\ & 29 & .048 & .568 \\ & 30 & .192 & .022^{*} \\ & 31 & .000 & .995 \\ & 32 & .104 & .217 \\ & 33 & .067 & .429 \\ & 34 & .096 & .254 \\ & 35 & -.004 & .966 \\ { }^{*} p<.05 & 36 & -.109 & .194 \\ & 37 & -.034 & .686\end{array}$

Table 7

Correlations Between Ethical Evaluations of Selected Distributive Practices and Grade Received in a Retail Buying Course

Slotting Allowances

Relativism

Contractualism

Moral Equity

Intentions

Incidence

Correlation

.052

$-.107$

$-.108$

.080

.099

Significance

.671

.381

.374

.508

.413

Diversion

Relativism

Contractualism

Moral Equity

Intentions

Incidence

Correlation

.085

.117

.054

.083

$-.083$

Significance

.671

.489

.656

.492

.493

Volume Discounts

Relativism

Contractualism

Correlation

$-.028$

Significance

.009

.816

.939

Moral Equity

Intentions

$-.128$

.295

$-.094$

.438

Incidence

$-.080$

.512

Expanding Distribution 
Relativism

Contractualism

Moral Equity

Intentions

Incidence
Correlation

$-.381$

$-.322$

$-.329$

$-.318$

$-.227$
Significance

$.001^{*}$

$.007^{*}$

$.006^{*}$

$.008^{*}$

.061

${ }^{*} p<.05$

A significant (at the .05 level) relationship was observed for only one item in each of the first two scales. One relationship was consistent with the hypothesis and the other was in the opposite direction. It appears, therefore, that the first two scales provide little evidence indicating that students' perceptions of potentially ethically troublesome situations are related to the grade received in a course in retail buying.

Regarding the third scale, significant (at the .05 level) relationships were not observed for any of the first three scenarios. No differences were observed for any of the factors of the MES, behavioral intentions, or for perceived prevalence of the practices depicted in the first three scenarios. Significant (at the .05 level) relationships were observed for the final scenario, however. Students receiving higher grades in the retail buying course were found to be significantly more likely to be disturbed about the practice on the all three of the factors of the MES (relativism, contractualism, and moral equity) than students receiving low grades. Students receiving higher grades were also significantly less likely to intend to pursue the practice. The findings are in a direction opposite of that hypothesized.

\section{Discussion}

Retailers have used several approaches to assess the ethical perceptions of potential employees, such as the commercially available Reid Survey (Cunningham \& Ash, 1988; Cunningham, Wong \& Barbee, 1994; Hogan \& Brinkmeyer, 1997; Wooley \& Hakstian, 1992). The use of the Reid Survey or similar instruments, however, is not without costs. In many instances, the cost of administering such measurements, both monetarily and temporally, makes the administration of these instruments difficult or even impossible, creating the desire for alternative evaluation methods.

The findings of this study suggest that it may be possible to gain some insight into the ethical perceptions of potential new retail employees merely by noting the grade a student may have received in a single course. The findings do not suggest that grades can be used to differentiate students in all areas of ethical activity, but it does suggest that grades may be used to differentiate between ethical evaluations and intentions in isolated areas. The scenario where significant relationships were observed between grades and ethical evaluations and intentions was the scenario that all parties in the Robicheaux and Robin (1996) study regarded as the most ethically disturbing and the one that they would be the least likely to pursue (lowest intentions). The scenario depicting the situation practitioners regard as the least ethical, therefore, is the scenario where significant relationships with grades were observed. 
The direction of the relationships observed for the scenario was in a direction opposite of that hypothesized, however. The higher the grade that students received in the course, the more likely that they are ethically troubled by the scenario and the less likely they would be to pursue the same action. Besides providing no evidence in support of the contentions of Lane, Schaupp and Parsons (1988), therefore, the results suggest that in at least some instances, the relationship may be a direction opposite of their hypothesis. This suggests that students' academic performance may not be result of, or facilitated by, lower ethics as suggested by Lane, Schaupp and Parsons (1988). Instead, the results support the positive relationship observed by Glover, Bumpus, Logan, and Ciesla (1997) between ethics and need for achievement. The results suggest that lower ethics may be a means by which individuals with lower academic performances may attempt to compete with their higher performing colleagues $-a$ relationship that this study suggests applies to ethical perceptions of the most egregious ethically questionable practices.

The findings suggest, therefore, that academic performance in a retail buying course may be used as a proxy by human resources in retail organizations to assess the ethical perceptions of potential new retail employees as they relate to actions clearly viewed as unethical by practitioners, but in a direction opposite of that hypothesized and only for isolated practices. Students receiving relatively higher grades in a retail buying course may be expected to be more troubled by, and less likely to intend to pursue, actions viewed as most ethically egregious.

The study possesses several limitations that may affect the generalizability of the results. First, the relative homogeneity of the sample (age, education level, and geographic location) limits the generalizability of the results to other samples. Second, ethical perceptions and intentions were examined, not actual decision making. Third, students' academic performance was measured based on their performance in a single class. The relationship between ethics and overall academic performance was not examined.

\section{Conclusion}

Although the ethical environment within an organization and the resulting activities of its employees can be affected through a number of means, not the least of which is the ethical standards exercised by the top management itself, the perceptions of potentially ethically troublesome issues held by the members of the organization such as a retail organization cannot be overlooked. Hence, the ethical perceptions of potential new employees cannot be disregarded.

Ultimately, the ethics displayed by a business, including those expressed by retailers, can be expected to affect the level of success experienced. Within a competitive environment, consumers and vendors alike possess choice, including the choice of retailers with which to do business. The choice of retailers with which to do business can logically be affected in part by the ethics displayed by the retailers under consideration. Retailers displaying a lower level of ethics will likely be viewed as less- 
desirable choices in many choice situations given the common manifestations of ethical shortcomings (e.g., less-truthful dealings, higher expenses, less choice). Consequently retailers need to purse all available options to ensure workforces that will deal ethically with external parties, with the selection of new employees with high ethical perceptions not being an exception. The results of this study suggest that viewing the grades received by prospective new employees in selected courses may serve as one possible option available to retailers to affect the ethics exhibited by their businesses.

\section{References}

Arbuthnot, J. J. (1997). Identifying ethical problems confronting small retail buyers during the merchandise buying process. Journal of Business Ethics, 16(7), 745755.

Atkinson, W. (2003). New buying tools present different ethical challenges. Purchasing, 132(4), 27-29.

Berner, R. (1996a, April 12). Kmart hires investigator as it expands probe of ties between staff, suppliers. Wall Street Journal, p. A4.

Berner, R. (1996b, July 30). Kmart is dismissing 12 managers from its purchasing department. Wall Street Journal, p. B4.

Bettencourt, L. A., Brown, S. W., \& Mackenzie, S. B. (2005). Customer-oriented boundary-spanning behaviors: Test of a social exchange model of antecedents. Journal of Retailing, 81(2), 141-157.

Brinkman, J. (2002). Moral reflection differences among Norwegian business students: A presentation and discussion of findings. Teaching Business Ethics, 6(1), 83-99.

Burns, D. J. (2004). Potentially ethically troublesome practices in the retail food industry: Relationship between intentions and perceived frequency of occurrence among future retail personnel. Electronic Journal of Business Ethics and Organization Studies, 9(2), 12-16.

Burns, D. J., \& Arbuthnot, J. J. (1998). Ethics in retail buying: Perceptions of future retail personnel: A preliminary examination. Presented at the American Collegiate Retailing Association Spring Meeting, Washington D.C.

Burns, D. J., \& Brady, J. T. (1996). Retail ethics as appraised by future business personnel in Malaysia and the United States. Journal of Consumer Affairs, 30(1), 195-217.

Burns, D. J., Lanasa, J. M., \& Fawcett, J. K. (1990). Ethical perceptions of undergraduate business students: Does the nature of the institution matter? Journal of Midwest Marketing, 5(1), 84-89.

Burns, D. J., \& Smith, P. W. (1990). Retail practices: Ethical perceptions of retail students. In B. J. Dunlap (Ed.), Developments in marketing science (pp. 407410). Cullowhee, NC: Academy of Marketing Science.

Chen, Y., \& Peng, S. S. (2008). University students' Internet use and its relationships with academic performance, interpersonal relationships, psychosocial adjustment, and self-evaluation. CyberPsychology \& Behavior, 11(4), 467-469.

Cunningham, M. R., \& Ash, P. (1988). The structure of honesty: Factor analysis of the Reid Report. Journal of Business and Psychology, 3(1), 54-66.

Cunningham, M. R., Wong, D. T., \& Barbee, A. (1994). Self presentation dynamics on 
overt integrity tests: Experimental studies of the Reid Report. Journal of Applied Psychology, 79(5), 643-658.

Daft, R. L., \& Noe, R. A. (2001). Organizational behavior. Fort Worth TX: Harcourt.

Delbecq, A. L., Van De Ven, A. H., \& Gustafson, D. H. (1975). Group techniques for program planning: A guide to nominal group and Delphi processes. Glenview, IL: Scott Foresman and Co.

Desplaces, D. E., Melcher, D. E., Beauvais, L. L., \& Bosco, S. M. (2007). The impact of business education on moral judgment competence: An empirical study. Journal of Business Ethics, 74(1), 73-87.

Donoho, C. L., Herche, J., \& Swenson, M. J. (2003). A cross-cultural study of the effects of achievement and relationship values on student evaluations of personal selling ethical dilemmas. Marketing Education Review, 13(3), 53-63.

Dornoff, R. J., \& Tankersley, C. B. (1975-76). Do retailers practice social responsibility? Journal of Retailing, 51(4), 33-42.

Dubinsky, A. J., \& Levy, M. (1985). Ethics in retailing: Perceptions of retail salespeople. Journal of the Academy of Marketing Science, 13(1-2), 1-16.

Dubinsky, A. J., Nataraajan, R., \& Huang, W. (2004). The influence of moral philosophy on retail salespeople's ethical perceptions. Journal of Consumer Affairs, 38(2), 297-319.

DuPont, A. M., \& Craig, J. S. (1996). Does management experience change the ethical perceptions of retail personnel: A comparison of the ethical perceptions of current students with those of recent graduates. Journal of Business Ethics, 15(8), 815826.

Ferrell, O. O., and Greham, L.G. (1985). A contingency framework for understanding ethical decision-making in marketing. Journal of Marketing, 49(3), 87-96.

Flanagan, P. (1994). The rules of purchasing are changing. Management Review, 83(3), 28-32.

Fraedrich, J., \& lyer, R. (2008). Retailers' major ethical decision making constructs. Journal of Business Research, 61(8), 834-841.

Gerlin, A. (1995a, February 7). Deals on the side: How a Penney buyer made up to $\$ 1.5$ million on vendors' kickbacks. Wall Street Journal, p. A1.

Gerlin, A. (1995b, August 28). JC Penney ex-employee sentenced to jail. Wall Street Journal, p. B5D.

Giese, M. R. (2004). Procurement fraud: Buyer beware. Loss Prevention, 3(2), 42-47.

Gifford, J. B., \& Norris, D. G. (1987). Ethical attitudes of retail store managers: A longitudinal analysis. Journal of Retailing, 63(3), 298-311.

Gillman, H. (1985, April 1). Bribery of retail buyers is called pervasive. Wall Street Journal, p. 6.

Glover, S. H., Bumpus, M. A., Logan, J. E., \& Ciesta, J. R. (1997). Re-examining the influence of individual values on ethical decision making. Journal of Business Ethics, 16(12/13), 1319-1329.

Greyser, S. A. (1981). Retail customer satisfaction and dissatisfaction. In E. Hirschman and R. W. Stampfl (Eds.), Theory in retailing: Traditional and nontraditional sources (pp. 64-70). Chicago: American Marketing Association.

Hart, C., Stachow, G. B., Farrell, A. M., \& Reed, G. (2007). Employer perceptions of skills gaps in retail: Issues and implications for UK retailers. International Journal of Retail \& Distribution Management, 35(4), 271-288. 
Hatch, M. J., \& Cunliffe, A. L. (2006), Organizational theory: Modern, symbolic, and postmodern perspectives. New York: Oxford University Press.

Hawthorne, T. L., Robin, D. P., \& Reidenbach. R. E. (1992). Identifying the gaps in ethical perceptions between managers and salespersons: A multidimensional approach. Journal of Business Ethics, 11(11), 849-856.

Hisey, P. (2002). The state of retail ethics. Retail Merchandiser, 42(5), 17-18.

Hogan, J., \& Brinkmeyer, K. (1997). Bridging the gap between overt and personalitybased integrity tests. Personnel Psychology, 50(3), 587-599.

Howe, V., Hoffman, K. D., \& Hardigree, D. W. (1994). The relationship between ethical and customer-oriented service provider behaviors. Journal of Business Ethics, 13(7), 497-506.

Hudson, S., \& Miller, G. (2005). Ethical orientation and awareness of tourism students. Journal of Business Ethics, 62(4), 383-396.

Inks, S., Avila, R., \& Chapman, J. (2004). A comparison of buyers' and sellers' perceptions of ethical behaviors within the buyer-seller dyad. Marketing Management Journal, 14(1), 117-128.

Klein, H., Levenburg, N., McKendall, M., \& Mothersell, W. (2007). Cheating during the college years: How do business school students compare? Journal of Business Ethics, 72(2), 197-206.

Kopp, R. J. (1993). Ethical issues in personal selling and sales force management. In N C. Smith \& J. A. Quelch (Eds.), Ethics in marketing (pp. 539-556). Homewood IL: Richard D. Irwin.

Lane, M. S., Schaupp, D., \& Parsons, B. (1988). Pygmalion effect: An issue for business education and ethics. Journal of Business Ethics, 7(7), 223-229.

Lewis, P. V. (1985). Defining 'business ethics:' Like nailing Jello to a wall, Journal of Business Ethics, 4(5), 377-383.

Levy, M., \& Dubinsky, A. J. (1983). Identifying and addressing retail salespeople's ethical problems: A method and application. Journal of Retailing, 59(1), 46-66.

Loo, K. H., Kennedy, J., \& Sauers, D. A. (1999). Are students really less ethical than business practitioners? Teaching Business Ethics, 2(4), 347-369.

Lopez, Y., Rechner, P. L., \& Olson-Buchanan, J. B. (2005). Empirical assessment of the influence of business education, culture, and demographic factors. Journal of Business Ethics, 60(4), 341-358.

Marta, J., Singhapakdi, A., \& Kraft, K. (2008). Personal characteristics underlying ethical decisions in marketing situations: A survey of small business managers. Journal of Small Business Management, 46(4), 589-606.

McMahon, J. M. (2003). An analysis of the factor structure of the multidimensional ethics scale and a perceived moral intensity scale, and the effects of moral intensity on ethical judgment. Dissertation Abstracts International: Section B: The Sciences and Engineering, 63(8-B), 39-67.

Mondy, R. W., Holmes, R. E., \& Flippo, E. B. (1983). Management: Concepts and practices. Newton MA: Allyn and Bacon.

Mujtaba, B., \& Sims, R. (2006). Socializing retail employees in ethical values: The effectiveness of the formal versus informal methods. Journal of Business \& Psychology, 21(2), 261-272.

Norris, D. G., \& Gifford, J. B. (1988). Retail store managers' and students' perceptions of ethical retail practices: A comparative and longitudinal analysis (1976-1986). 
Journal of Business Ethics, 7(7), 515-524.

Park, H., \& Stoel, L. (2005). A model of socially responsible buying/sourcing decisionmaking processes. International Journal of Retail \& Distribution Management, 33(4), 235-248.

Pettijohn, C., Pettijohn, L., \& Taylor, A. (2008). Salesperson perceptions of ethical behaviors: Their influence on job satisfaction and turnover intentions. Journal of Business Ethics, 78(4), 547-557.

Pregman, M. J. (1997). Do your part for an ethical supply chain. Transportation \& Distribution, 38(3), 108.

Pretious, M., \& Love, M. (2006). Sourcing ethics and the global market: The case of the UK retail clothing sector. International Journal of Retail and Distribution Management, 34(12), 882-903.

Razzaque, M. A., \& Hwee, T. P. (2002). Ethics and purchasing dilemma: A Singaporean view. Journal of Business Ethics, 35(4), 307-326.

Reardon, J., Payan, J., Miller, C., \& Alexander, J. (2008). Optimal class length in marketing undergraduate classes: An examination of preference, instructor evaluations, and student performance. Journal of Marketing Education, 30(1), 1220.

Reidenbach, R. E., \& Robin, D. P. (1988). Some initial steps toward improving the measurement of ethical evaluations of marketing activities. Journal of Business Ethics, 7(10), 871-879.

Reidenbach, R. E., \& Robin, D. P. (1990). Toward the development of a multidimensional scale for improving evaluations of business ethics. Journal of Business Ethics, 9(8), 639-653.

Reidenbach, R. E., Robin, D. P., \& Dawson, L. (1991). An application and extension of a multidimensional ethics scale to selected marketing practices and marketing groups. Journal of the Academy of Marketing Science, 19(2), 83-92.

Robbins, S. P. (2003). Organizational behavior. Upper Saddle River NJ: Prentice-Hall.

Roberts, K. H., \& Hunt, D. M. (1991). Organizational behavior. Boston: PWS-Kent Publishing.

Robicheaux, R. A., \& Robin, D. P. (1996). Ethical evaluations of selected distributive practices. In William R. Darden (Ed.), The cutting edge IV (pp. 431-440). Baton Rouge LA: Louisiana State University.

Román, S., \& Ruiz, S. (2005). Relationship outcomes of perceived ethical sales behavior: The customer's perspective. Journal of Business Research, 58(4), 439445.

Sarma, N. N. (2007). Ethics in retailing: Perceptions of management and sales personnel. In Proceedings from the International Marketing Conference on Marketing \& Society (pp.61-68). Kozhikode India: Indian Institute of Management.

Schwartz, M. S., \& Weber, J. (2006). A business ethics national index (BENI): Measuring business ethics activity around the world. Business \& Society, 45(3), 382-405.

Schwepker, Jr., C. H., \& Good, D. J. (2007). Sales management's influence on employment and training in developing an ethical sales force. Journal of Personal Selling \& Sales Management, 27(4), 325-339.

Smith, K. J., Davy, J. A., \& Easterling, D. (2004). An examination of cheating and its 
antecedents among marketing and management majors. Journal of Business Ethics, 50(1), 63-80.

Smith, K. J., Davy, J. A., Rosenberg, D. L., \& Haight, G. T. (2002). A structural modeling investigation of the influence of demographic and attitudinal factors and in-class deterrents on cheating behaviors among accounting majors. Journal of Accounting Education, 20(1), 45-65.

Spake, D. F., Megehee, C. M., \& Franke, G. R. (2007). Students' views of ethical behavior and the impact of association. Marketing Education Review, 17(3), 3347.

Stevenson, T. H., \& Bodkin, C. D. (1998). A cross-national comparison of university students' perceptions regarding the ethics and acceptability of sales practices. Journal of Business Ethics, 17(1), 45-55.

Stoner, J. A. F., \& Freeman, R. E. (1989). Management. Englewood Cliffs NJ: Prentice Hall.

Telford, D., \& Gostick, A. (2005). Hiring character. Sales \& Marketing Management, 157(6), 39-42.

Terpstra, D. E., Rozell, E. J., \& Robinson, R. K. (1993). The influence of personality and demographic variables on ethical decisions related to insider trading. Journal of Psychology, 127(4), 375-389.

Velasquez, M. G. (2006). Business ethics: Concepts and cases. Upper Saddle River NJ: Prentice Hall.

Vitell, S., Singh, J., \& Paolillo, J. (2007). Consumers' ethical beliefs: The roles of money, religiosity and attitude toward business. Journal of Business Ethics, 73(4), 369379.

Wooley, R. M., \& Hakstian, A. R. (1992). An examination of the construct validity of personality-based and overt measures of integrity. Educational and Psychological Measurement, 52(2), 475-489.

Zimmerman, A. (2007, August 2). Home Depot fires employees amid probe of kickbacks. Wall Street Journal, 250, p. A2. 